African Crop Science Journal by African Crop Science Society is licensed under a Creative Commons Attribution 3.0 Uganda License. Based on a work at www.ajol.info/ and www.bioline.org.br/cs DOI: https://dx.doi.org/10.4314/acsj.v28i1.7S

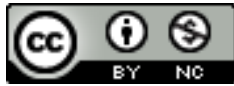

\title{
GENOTYPE AND PLANT DENSITY EFFECTS ON OIL CONTENT AND FATTY ACID COMPOSITION OF SAFFLOWER
}

\author{
O.G. MOATSHE, V.E. EMONGOR, T.V. BALOLE ${ }^{1}$ and S.O. TSHWENYANE ${ }^{1}$ \\ Department of Agricultural Research, Private Bag 0033, Gaborone, Botswana, Africa \\ ${ }^{1}$ Botswana University of Agriculture and Natural Resources, Crop Science and Production \\ Department, Private Bag 0027, Gaborone, Botswana, Africa \\ Corresponding author: vemongor@buan.ac.bw, vemongor@gmail.com
}

\begin{abstract}
Safflower (Carthamus tinctorius L.) is a multipurpose oilseed crop that is tolerant to drought, saline, heat and cold conditions; and yields high quality edible seed oil. The objective of this study was to evaluate the effect of plant density and genotypes on oil content and fatty acid composition of safflower. A field experiment was conducted in the years 2015 and 2016, during winter and summer seasons. Treatments included five safflower genotypes and six plant densities. Genotype and plant density significantly interacted $(\mathrm{P}<0.05)$ to influence oil content and fatty acid composition of safflower. Increasing plant density from 62,500 to 100,000 plants ha $^{-1}$ significantly $(\mathrm{P}<0.05)$ increased the oil concentration from 16 to $54 \%$, depending on the interaction between genotype and plant density and genotype by environment (winter and summer seasons). However, as plant density increased from 100,000 to 200,000 plants ha ${ }^{-1}$, safflower oil content significantly $(\mathrm{P}<0.05)$ decreased in all genotypes. The lowest and highest oil contents was produced by genotype 'Gila' planted at density 62,500 or 200,000; and 'Sina', 'Pi 537636 ' at 100000 or 125,000 plants ha' ${ }^{-1}$ in winter or summer, respectively. Fatty acid composition was significantly influenced by genotype and plant density interactions during the two growing seasons. The main fatty acids identified included linoleic, oleic, stearic and palmatic. There was a significant $(\mathrm{P}<0.05)$ increase in linoleic acid content and a decrease in oleic, palmatic and stearic as plant density increased from 62,500 to 100,000 plants ha ${ }^{-1}$, depending on genotype or growing season. Genotype 'Sina' at 100,000 plants ha ${ }^{-1}$ produced the highest oil content and with high unsaturated fatty acid concentrations.
\end{abstract}

Key Words: Carthamus tinctorius, oleic, linoleic, palmatic

\section{RÉSUMÉ}

Le carthame (Carthamus tinctorius L.) est une plante de graines oléagineuses polyvalente qui est tolérante à la sécheresse, à la salinité, à la chaleur et au froid; et il donne de l'huile de graines comestibles de haute qualité. L'objectif de cette étude était d'évaluer l'effet de la densité et des génotypes des plantes sur la teneur en huile et la composition en acides gras du carthame. Une expérience sur le terrain a été menée en 2015 et 2016, pendant les saisons d'hiver et d'été. Les traitements comprenaient 
cinq génotypes de carthame et six densités de plantes. Le génotype et la densité des plantes ont interagi de manière significative $(\mathrm{P}<0,05)$ pour influencer la teneur en huile et la composition en acides gras du carthame. L'augmentation de la densité des plantes de 62500 à 100000 plantes ha $^{-1}$ de manière significative $(\mathrm{P}<0,05)$ a augmenté la concentration d'huile de 16 à $54 \%$, selon l'interaction entre le génotype et la densité des plantes et le génotype par environnement (saisons d'hiver et d'été). Cependant, comme la densité des plantes est passée de 100000 à 200000 plantes ha $^{-1}$, la teneur en huile de carthame de manière significative $(\mathrm{P}<0,05)$ a diminué dans tous les génotypes. Les teneurs en huile les plus basses et les plus élevées ont été produites par le génotype «Gila» planté à une densité de 62500 ou 200 000; et «Sina», «Pi 537 636» à 100000 ou 125000 plantes ha ${ }^{-1}$ en hiver ou en été, respectivement. La composition en acides gras a été significativement influencée par les interactions entre le génotype et la densité des plantes au cours des deux saisons de croissance. Les principaux acides gras identifiés étaient les acides linoléique, oléique, stéarique et palmatique. Il y a eu une augmentation significative $(\mathrm{P}<0,05)$ de la teneur en acide linoléique et une diminution de l'oléique, palmatique et stéarique lorsque la densité des plantes est passée de 62500 à 100000 plantes ha $^{-1}$, selon le génotype ou la saison de croissance. Le génotype «Sina» de 100000 plantes ha $^{-1}$ a produit la teneur en huile la plus élevée et avec des concentrations élevées en acides gras insaturés.

Mots Clés: Carthamus tinctorius, oléique, linoléique, palmatique

\section{INTRODUCTION}

Among the oil seed crops, safflower (Carthamus tinctorius $\mathrm{L}$.) ranks the eighth after soybean, ground nut, rape seed, sunflower, sesame, linseed and castor crops (Dwivedi et al., 2005). Interest in cultivation of safflower has increased because of increased demand for vegetable oil for biodiesel and edible oil (Mailer et al., 2008). There is a huge shortfall in oilseed production in semi-arid and arid countries, which can grow safflower which is drought and saline tolerant (Bannayan et al., 2008; Mollasadeghi et al., 2011; Emongor et al., 2017).

Interest in the cultivation of safflower as a source of edible oil has further been stimulated by the understanding that safflower oil is a rich source of polyunsaturated essential fatty acid, linoleic acid (70-87\%) and mono unsaturated fatty acid oleic acid (11-80\%) (Murthy and Anjani, 2008; Aghamohammadreza et al., 2013; Liu et al., 2016). Linoleic acid has been shown to offer nutritional and therapeutic benefits such as prevention of coronary heart disease, diabetes type II, arteriosclerosis, lowers serum cholesterol, high blood pressure and hyper- lipaemia (Smith, 1996; Cosge et al., 2007; Guan et al., 2008; Han et al., 2009; Liu et al., 2016). The standard fatty acid composition of safflower oil is $6-8 \%$ palmitic acid, 2 $3 \%$ stearic acid, 16 - $20 \%$ oleic acid and 71 75\% linoleic acid (Velasco and FernandezMartinez, 2001). The seeds of safflower are also a rich source of minerals $(\mathrm{Zn}, \mathrm{Cu}, \mathrm{Mn}$ and $\mathrm{Fe}$ ), vitamins (thiamine and $\beta$-carotene) and tocopherols $\alpha, \beta$ and $\gamma$ (Velasco et al., 2005; Phuduhudu, 2017). It has an oil content ranging between 20 to $45 \%$, depending on genotype, environment and cultural practices (Emongor et al., 2017; Oarabile, 2017).

In spite of the high quality and nutritional value of safflower oil, the crop has remained underutilised and neglected as it accounts for less than $1 \%$ of the world annual oil seed production (Weiss, 2000; Emongor, 2010). There is a significant variation in safflower oil content, yield and fatty acid composition which is influenced by genetic factors, location, season, temperature, agronomic practices, time of planting and plant density (Liu et al., 2016; Oarabile, 2017; Emongor et al., 2017; Sampaio et al., 2017; Khan et al., 2018).

Safflower plant density and genotype are reported to significantly influence oil content 
and fatty acid composition (Cucci et al., 2012; Ibrahim, 2012; Sarkees and Mohammed, 2016). Sarkees and Mohammed (2016) reported that increasing safflower plant density from 133,300 to 200,000 plants $\mathrm{ha}^{-1}$ increased linoleic and oleic fatty acids, but decreased the stearic and palmitic fatty acids contents, respectively. Above 200,000 plants ha ${ }^{-1}$, linoleic and oleic fatty acids contents decreased; while palmitic and stearic fatty acids increased (Sarkees and Mohammed, 2016). Safflower genotypes 'Gila' and 'Almais' at 666,700 plants ha ${ }^{-1}$ had the highest oleic fatty acid composition of 15.2 and $13.6 \%$; while genotype 'Almais' at 200,000 plants $\mathrm{ha}^{-1}$ had the highest linoleic fatty acid content of $79.9 \%$, but stearic fatty acid content was highest at 333,000 plants ha $^{-1}$; and palmitic fatty acid was highest at 133,333 plants ha ${ }^{-1}$ in all genotypes (Sarkees and Mohammed, 2016).

Oad et al. (2002) reported that increasing safflower plant density from 74,074 to 266,667 plants ha ${ }^{-1}$ decreased seed oil content from 31.63 to $29.63 \%$. Emongor et al. (2013) studied genotype 'Kiama Composite' in Botswana and reported that increasing density from 100,000 to 250,000 plants ha $^{-1}$, decreased seed oil content. Amoughein et al. (2012) reported that increasing safflower plant density from 30,000 to 60,000 plants $\mathrm{ha}^{-1}$, decreased seed oil content from 21.16 to $19.34 \%$. Most studies on safflower plant density has been based on its impact on vegetative growth, seed yield, yield components and oil content under different genotypes; and cropping systems (Amoughein et al., 2012; Emongor et al., 2013; Emongor and Oagile, 2017; Sampaio et al., 2017). However, information on the influence of safflower plant density and genotype on oil content and composition in the sub-Saharan environment is still unavailable, except the work of Emongor $e t$ al. (2015) which is not sufficient. Therefore, the objective of this study was to evaluate the influence of safflower plant density and genotypes on seed oil content and fatty acid profiles in Botswana.

\section{MATERIALS AND METHODS}

Experimental site. A field experiment was carried out at the Botswana University of Agriculture and Natural Resources Farm (59 $24^{\prime} \mathrm{S}, 95^{\circ} 25^{\prime} \mathrm{E}$ and $993 \mathrm{~m}$ above sea level) in 2015 and 2016, both in summer and winter. The soils are shallow, ferruginous and tropical, mainly consisting of medium to coarse grain sandy loams (De Wilt and Nachtengale, 1996). In the university area, rainfall amount and evapotranspiration varies between 250-600 and 1800-3000 mm per annum. The winter (midMay until mid-September), temperatures ranges between $-1^{\circ} \mathrm{C}$ (morning) to $30^{\circ} \mathrm{C}$ (afternoon); while summer (mid-September to late mid-May) temperature ranges between $20^{\circ} \mathrm{C}$ (morning) to $37^{\circ} \mathrm{C}$ (afternoon) (Burgess, 2006).

Treatments and design. Treatments included five safflower genotypes and six plant densities; namely $200,000(25 \mathrm{~cm}$ x $20 \mathrm{~cm})$, $166,666(30 \mathrm{~cm} \times 20 \mathrm{~cm}), 125,000(40 \mathrm{~cm} \times$ $20 \mathrm{~cm}), 100,000(40 \mathrm{~cm} \times 25 \mathrm{~cm}), 83,333$ $(40 \mathrm{~cm} \times 30 \mathrm{~cm})$ and $62,500(40 \mathrm{~cm} \times 40 \mathrm{~cm})$ plants $\mathrm{ha}^{-1}$. Safflower genotypes included Kiama Composite (local), PI-537598-Sina, PI537692-Gila, PI-537636 and PI- 527710. The experiment was laid out in a split-plot arrangement in randomised complete block design (RCBD), with three replications. Plant densities were the main plots, and genotypes were the subplots. The sub-plots were $3 \mathrm{~m} \mathrm{x}$ $3 \mathrm{~m}$; while the main-plots were $10 \mathrm{~m} \times 7 \mathrm{~m}$.

Cultural practices. The land was bush cleared, ploughed and disc harrowing into a fine soil tilth. Soil was sampled using a zigzag layout plan, at a depth of $30 \mathrm{~cm}$, using soil auger to determine mineral composition prior to planting. Basal fertiliser application was done at rates $60 \mathrm{~kg} \mathrm{ha}^{-1}$ nitrogen and $30 \mathrm{~kg} \mathrm{ha}$ ${ }^{1}$ phosphorus and $20 \mathrm{~kg} \mathrm{ha}^{-1}$ potassium (FAO, 2013). Safflower seed was sown directly at the rate of 2 seeds per hill at a depth of approximately $4.5 \mathrm{~cm}$. This was followed by 
thinning at 15 days after emergence. Management practices such as pests, disease and weed control were undertaken where necessary, following routine practices in the area.

The amount of water applied was according to the crop water requirements (ETm) as related to reference evapotranspiration (FAO, 2013). The average water recommended for safflower growing ranges between 600-1200 $\mathrm{mm}$ per growth period, depending on climate and length of plant growth period (FAO, 2013). Irrigation was done once a week for 2 hours (11 mm) using over overhead sprinkler irrigation to all experimental units.

Seed yield. Seed yield was estimated from plants growing in a $4 \mathrm{~m}^{2}$ area (centre of the plot). The seeds/grains were threshed and winnowed manually from the sample, prior to determining seed yield per unit area. The seeds were used for oil content and oil composition profiling.

Oil content. Safflower seeds were air-dried and ground using a porcelain pestle and mortar. A total of $20 \mathrm{~g}$ of the ground seed sample was used for oil content. Determination was done using the soxhlet extraction method of AOACS (2004). A 3:1 hexane: iso-propanol mixture was used with a boiling range of $60-80{ }^{\circ} \mathrm{C}$ for $8 \mathrm{hr}$. After extraction, the oil content was expressed as follows:

Oil content $(\%)=[\mathrm{Wo} / \mathrm{Ws}] \times 100$

Where:

Wo = weight of oil extracted; Ws = weight of seed extracted

Fatty acid methyl esters. Part of the extracted oil sample was used to prepare fatty acid methyl esters (FAME), through acidcatalysed trans-esterification (AOAC, 1996).
Statistical analysis. Analysis of variance was performed on the data using the General Linear Model (PROC GLM) procedure of Statistical Analysis System (SAS 2009, Carey, NC) programme. Multiple comparisons among means were done using Protected Least Significant Difference (LSD) at $\mathrm{P}=0.05$.

\section{RESULTS}

Oil content. Safflower genotype and plant density had a significant $(\mathrm{P}<0.05)$ interaction on oil content irrespective of season (Figs. 14). Safflower oil content increased as plant density increased from 62,500 to 100,000 plants $\mathrm{ha}^{-1}$; and thereafter the oil content decreased in all genotypes. Safflower planted at 100,000 plants $\mathrm{ha}^{-1}$ had the highest oil content in all genotypes, irrespective of season. Genotype 'Gila' had significantly $(\mathrm{P}<0.05)$ the lowest seed oil content among all genotypes in all plant densities. However, the maximum oil content was significantly $(\mathrm{P}<0.05)$ variable depending on genotypes, plant density and season (Figs. 1 - 4). Genotypes 'PI-527710' and 'Sina' at 83,333 and 100,000 plants ha-1 in winter of 2015 produced the maximum oil content of $54.97 \%$. In summer of 2015 and 2016, on the other hand, genotype 'PI-537 636' planted at 125,000 and 100,000 plants ha $^{-1}$ produced maximum oil content of 56.55 and $55.82 \%$, respectively (Figs. 2 and 4). Seed oil content ranged between $16-56 \%$ in both years. The lowest oil content of $16.09 \%$ was produced by genotype 'Gila' planted at 200,000 plants ha-1 in summer of 2015 (Fig. 2). While the highest seed oil content of $56.55 \%$ was produced by genotype 'PI-537636' at 100,000 plants ha-1 grown in summer of 2015 (Fig. 2). However, genotype 'Sina' had the most stable seed oil content, irrespective of plant density and growing season (Figs. 1- 4). For example, at 100,000 plants $\mathrm{ha}^{-1}$ in both winter and summer of 2015 and 2016, the seed oil content of genotype 'Sina' ranged between 54.59 to $56.14 \%$ (Figs. 1- 4). 


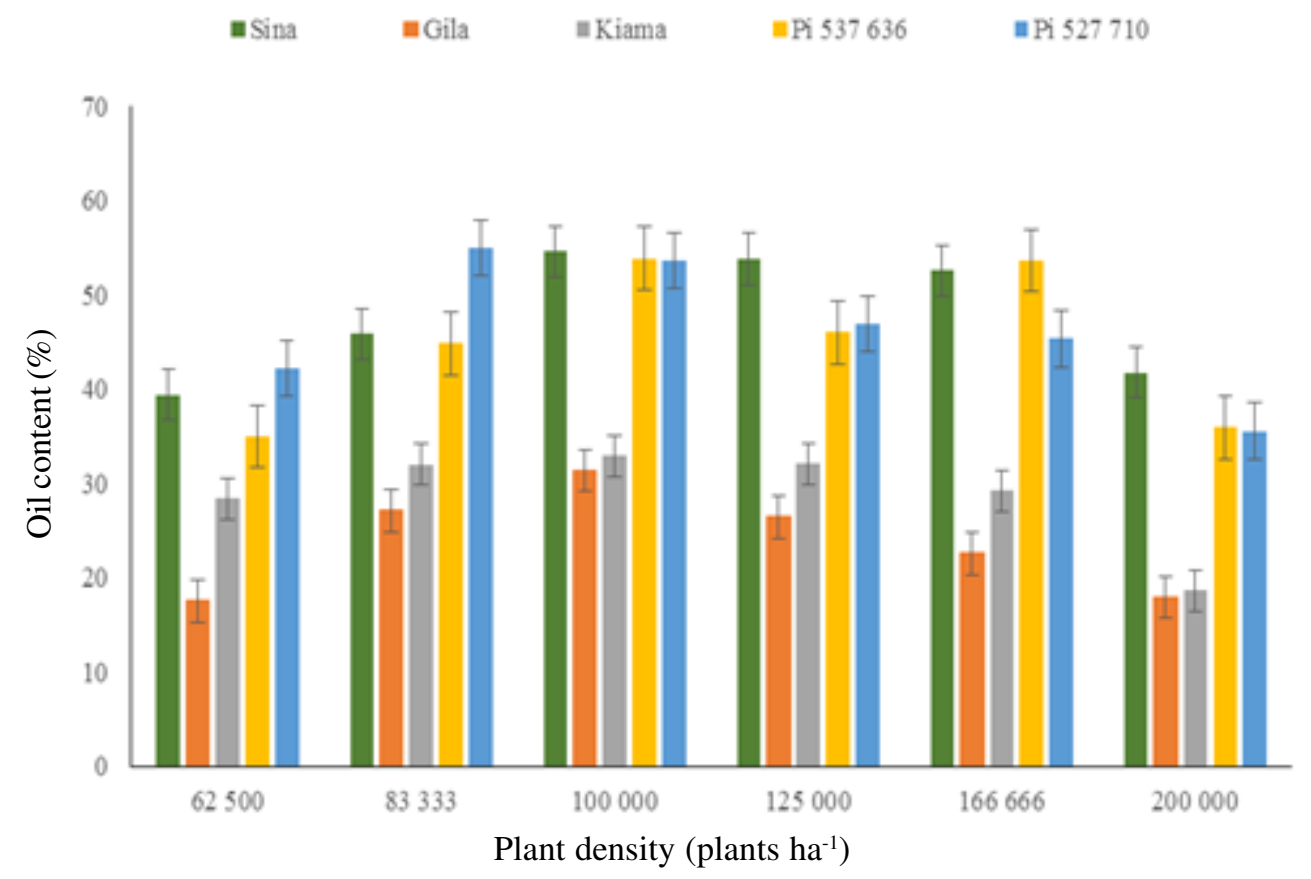

Figure 1. Effect of genotype and plant density on oil content of safflower grown in winter 2015; bars are standard error.

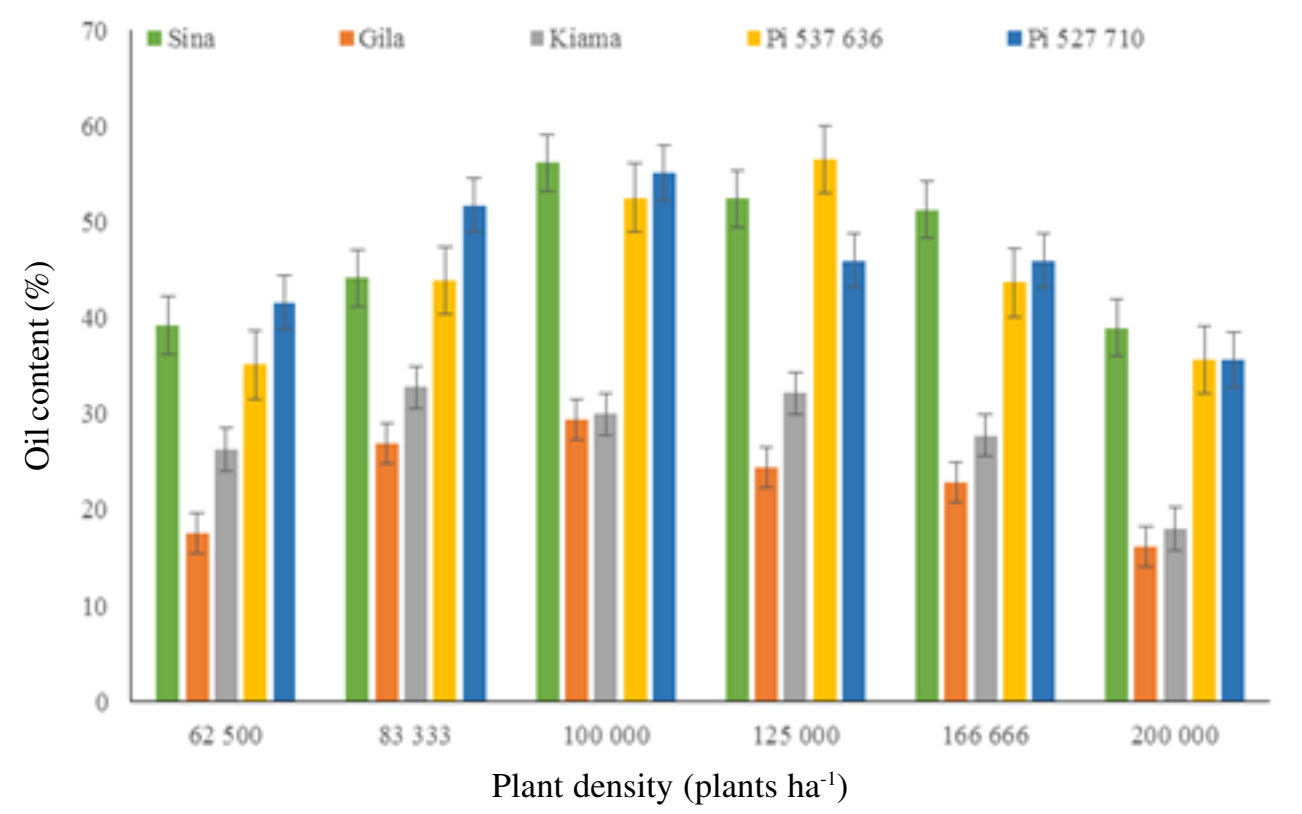

Figure 2. Effect of genotype and plant density on oil content of safflower grown in summer 2015; bars are standard error. 


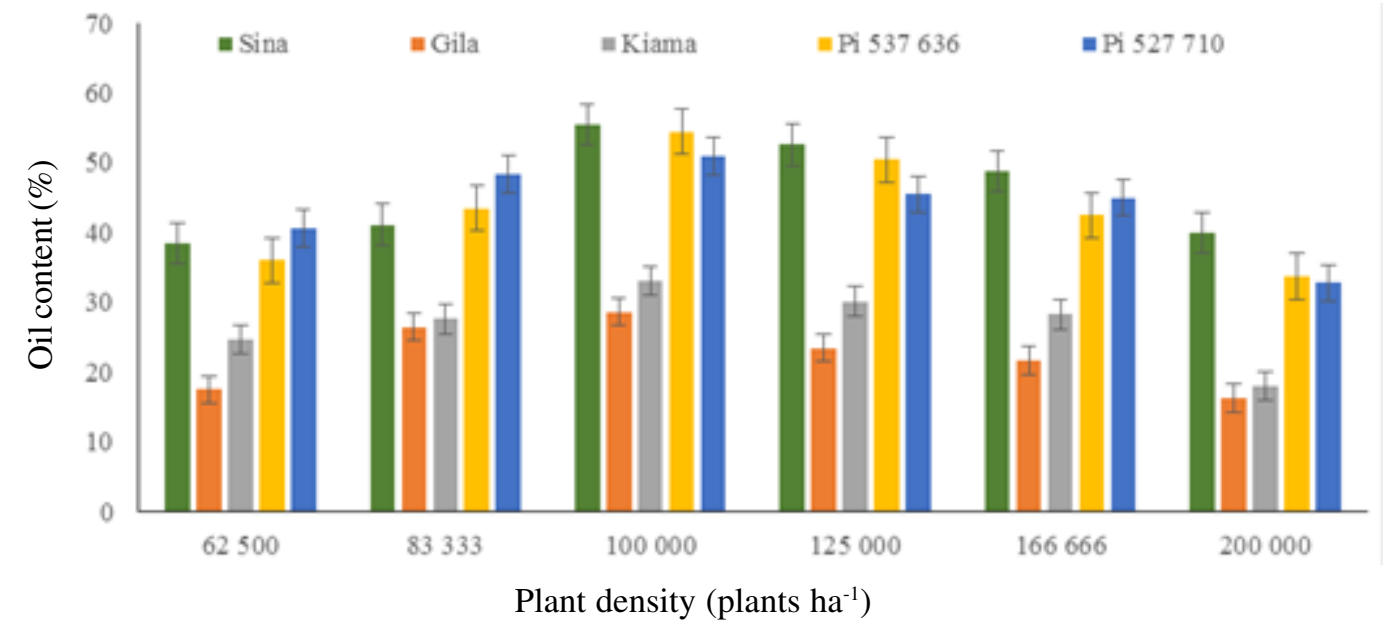

Figure 3. Effect of genotype and plant density on oil content of safflower grown in winter 2016; bars are standard error.

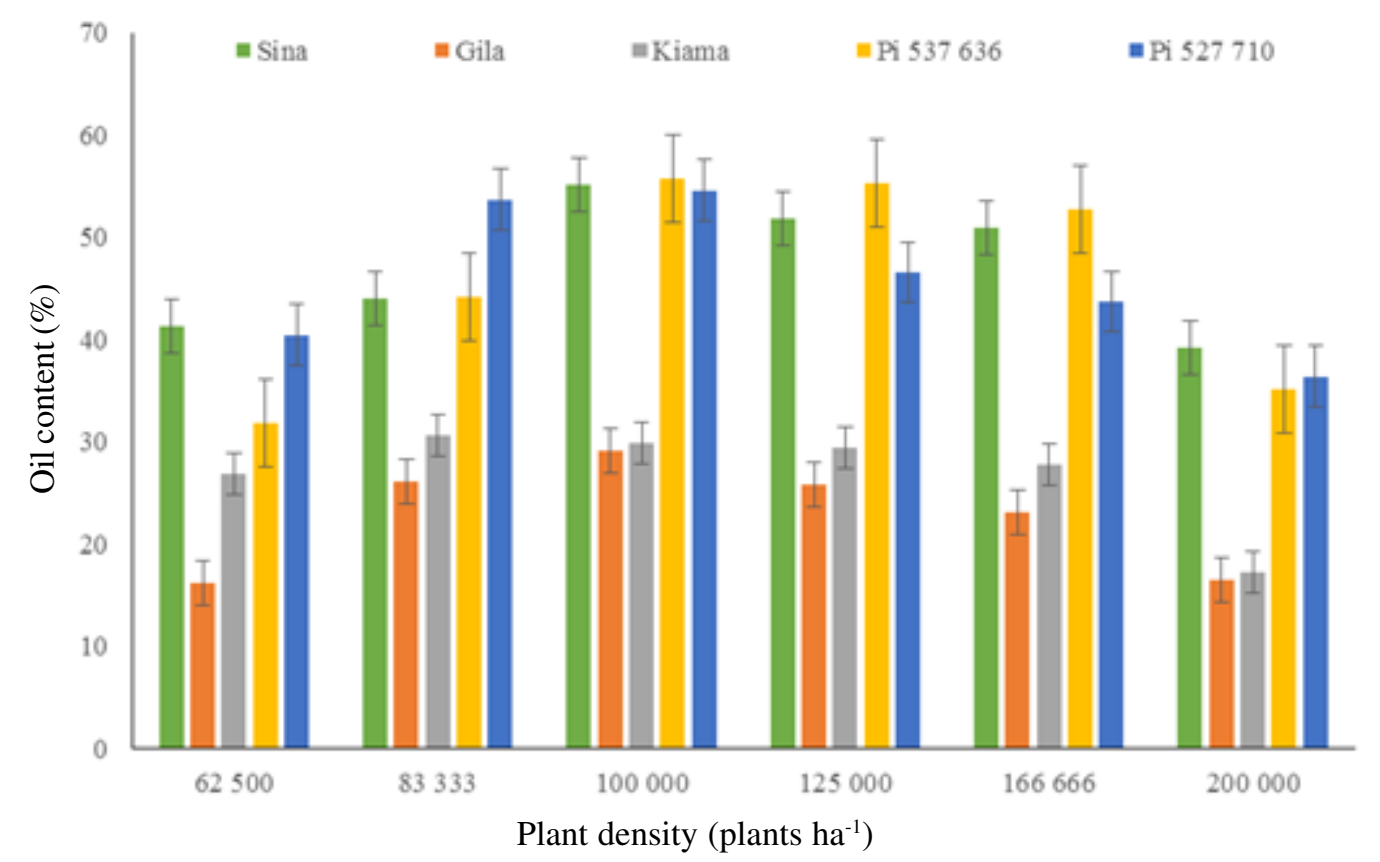

Figure 4. Effect of genotype and plant density on oil content of safflower grown in summer 2016; bars are standard error. 
During winter of 2015, the oil content of genotypes 'Sina' at 100,000, 125,000 and 166,666 plants ha $^{-1}$, 'PI-527710' at 83,333 and 100,000 plants ha ${ }^{-1}$, and 'PI- 537636' at 100,000 plants ha ${ }^{-1}$, did not significantly $(\mathrm{P}>$ $0.05)$ differ, but was significantly $(\mathrm{P}<0.05)$ higher than the seed oil content of all other genotypes planted in various plant densities (Fig. 1). In contrast, in summer, genotypes 'PI-537636' at 100,000 and 125,000 plants ha $^{-1}$, and 'PI-527710' and 'Sina' at 100,000 plants ha ${ }^{-1}$, did not significantly $(\mathrm{P}>0.05)$ vary, but was significantly $(\mathrm{P}<0.05)$ higher than the seed oil content of other genotypes planted in various plant densities (Fig. 2).

A similar response was observed in winter of 2016 where genotypes 'PI-537636' at 100,000 and 125,000 plants ha' ${ }^{-1}$, and 'PI-
527710' and 'Sina' at 100,000 plants ha ${ }^{-1}$, did not significantly $(\mathrm{P}>0.05)$ vary, but was significantly $(\mathrm{P}<0.05)$ higher than seed oil content of other genotypes in all plant densities (Fig. 3). During summer of 2016, genotypes 'PI-527710' planted at 83,333 and 100,000 plants ha ${ }^{-1}$, 'Sina' planted at 100,000 plants ha $^{-1}$, and 'PI-537636' planted at 100,000 and 125,000 plants ha $^{-1}$, produced seed oil contents with no significant $(\mathrm{P}>0.05)$ difference, but was significantly $(\mathrm{P}<0.05)$ higher than the seed oil content of other genotypes in all plant densities (Fig. 4).

Fatty acid composition. Genotype and plant density had a significant $(\mathrm{P}<0.05)$ interaction on fatty acid composition of safflower in winter and summer (Tables 1- 5, Figs. 5-10). The

TABLE 1. Effect of genotype and plant density on linoleic acid content (\%) of safflower oil under different seasons

\begin{tabular}{|c|c|c|c|c|c|}
\hline Plant density (plants ha ${ }^{-1}$ ) & Sina & Gila & Kiama & PI-527710 & PI-537636 \\
\hline \multicolumn{6}{|l|}{ Winter } \\
\hline 62,500 & 71.47 & 57.51 & 56.98 & 58.56 & 62.65 \\
\hline 83,333 & 72.49 & 65.37 & 61.58 & 67.31 & 68.00 \\
\hline 100,000 & 76.61 & 69.75 & 68.70 & 73.80 & 77.75 \\
\hline 125,000 & 76.01 & 62.91 & 62.14 & 67.03 & 72.47 \\
\hline 166,666 & 75.40 & 59.19 & 54.00 & 67.46 & 64.48 \\
\hline 200,000 & 67.44 & 64.55 & 67.61 & 62.42 & 58.85 \\
\hline Significance & $* * * *$ & $* * * *$ & $* * * *$ & $* * * *$ & $* * * *$ \\
\hline $\operatorname{LSD}(0.05)$ & 0.59 & 0.59 & 0.59 & 0.59 & 0.59 \\
\hline \multicolumn{6}{|l|}{ Summer } \\
\hline 62,500 & 68.44 & 57.11 & 54.28 & 58.22 & 62.34 \\
\hline 83,333 & 74.94 & 68.94 & 59.78 & 63.27 & 67.14 \\
\hline 100,000 & 75.46 & 71.12 & 67.25 & 70.26 & 74.62 \\
\hline 125,000 & 75.07 & 61.58 & 62.74 & 67.09 & 70.84 \\
\hline 166,666 & 67.55 & 57.65 & 59.56 & 61.72 & 60.14 \\
\hline 200,000 & 64.61 & 57.71 & 58.83 & 62.25 & 56.92 \\
\hline Significance & $* * * *$ & $* * * *$ & $* * * *$ & $* * * *$ & $* * * *$ \\
\hline $\operatorname{LSD}(0.05)$ & 0.43 & 0.43 & 0.43 & 0.43 & 0.43 \\
\hline
\end{tabular}

**** Significance at $\mathrm{P}=0.0001$, respectively. Means separated using the Least Significant Difference (LSD) at $\mathrm{P}=0.05$ 
TABLE 2. Effect of genotype and plant density on oleic acid content (\%) of safflower oil under different seasons

\begin{tabular}{|c|c|c|c|c|c|}
\hline Plant density (plants ha' ${ }^{-1}$ ) & Sina & Gila & Kiama & PI-527710 & PI-537636 \\
\hline \multicolumn{6}{|l|}{ Winter } \\
\hline 62,500 & 16.12 & 21.08 & 22.16 & 21.29 & 19.89 \\
\hline 83,333 & 15.03 & 16.98 & 20.57 & 17.84 & 18.08 \\
\hline 100,000 & 12.88 & 19.08 & 16.44 & 14.71 & 11.37 \\
\hline 125,000 & 12.93 & 19.95 & 20.87 & 18.63 & 15.91 \\
\hline 166,666 & 11.05 & 20.81 & 23.17 & 17.60 & 20.02 \\
\hline 200,000 & 17.38 & 19.04 & 18.28 & 20.06 & 21.59 \\
\hline Significance & $* * * *$ & $* * * *$ & $* * * *$ & $* * * *$ & $* * * *$ \\
\hline $\operatorname{LSD}(0.05)$ & 0.24 & 0.24 & 0.24 & 0.24 & 0.24 \\
\hline \multicolumn{6}{|l|}{ Summer } \\
\hline 62,500 & 17.61 & 19.58 & 23.42 & 21.02 & 20.68 \\
\hline 83,333 & 14.22 & 16.28 & 20.85 & 19.52 & 17.83 \\
\hline 100,000 & 13.53 & 16.89 & 17.80 & 16.18 & 14.06 \\
\hline 125,000 & 13.33 & 20.98 & 20.13 & 17.87 & 16.51 \\
\hline 166,666 & 19.08 & 21.46 & 20.81 & 20.68 & 20.99 \\
\hline 200,000 & 18.16 & 21.43 & 21.30 & 20.18 & 21.99 \\
\hline Significance & $* * * *$ & $* * * *$ & $* * * *$ & $* * * *$ & $* * * *$ \\
\hline $\operatorname{LSD}(0.05)$ & 0.34 & 0.34 & 0.34 & 0.34 & 0.34 \\
\hline
\end{tabular}

**** Significance at $\mathrm{P}=0.0001$, respectively. Means separated using the Least Significant Difference (LSD) at $\mathrm{P}=0.05$

main fatty acids identified in safflower oil were linoleic, oleic, palmatic, and stearic (Tables 14). The minor fatty acids were arachidic, isostearic and iso-oleic acid varying with plant density, genotype and season (Figs. 5-10). There was a significant $(\mathrm{P}<0.05)$ interaction of safflower genotype and plant density on linoleic acid content (Table 2). Linoleic fatty acid content significantly $(\mathrm{P}<0.05)$ increased with increase in plant density from 62,500 to 100,000 plants $\mathrm{ha}^{-1}$, and thereafter, linoleic acid content decreased in all genotypes grown either in winter or summer grown (Table 1). Linoleic fatty acid content significantly $(\mathrm{P}<$ 0.05 ) ranged between $54-78$ and $54-75 \%$ in winter and summer, respectively (Table 2). Safflower planted at 100,000 plants $\mathrm{ha}^{-1}$ produced oil with high linoleic acid content from genotypes 'PI-537636' (78\%) and 'Sina' $(75 \%)$ in winter and summer, respectively (Table 1).

In general, genotype 'Sina' had significantly $(\mathrm{P}<0.05)$ higher linoleic acid content than all other genotypes within a given plant density, with exception in winter when genotype 'PI-537636' at 100,000 plants ha-1 which had significantly $(\mathrm{P}<0.05)$ higher linoleic acid content than genotype 'Sina' (Table 1). Linoleic acid content of genotype 'Sina' planted at 100,000 and 125,000 plants $\mathrm{ha}^{-1}$ did not significantly $(\mathrm{P}>0.05)$ differ, but was significantly $(\mathrm{P}<0.05)$ higher than the linoleic acid content of all other genotypes, with exception of 'PI-537636' at 100,000 plants ha' ${ }^{1}$ or 'Kiama' at 200, 000 plants ha ${ }^{-1}$ (Table 1). 
TABLE 3. Effect of genotype and plant density on palmitic acid content (\%) of safflower oil under different seasons

\begin{tabular}{|c|c|c|c|c|c|}
\hline Plant density (plants ha ${ }^{-1}$ ) & Sina & Gila & Kiama & PI-527710 & PI-537636 \\
\hline \multicolumn{6}{|l|}{ Winter } \\
\hline 62,500 & 8.66 & 13.75 & 13.10 & 12.75 & 11.47 \\
\hline 83,333 & 9.89 & 10.73 & 11.90 & 10.40 & 9.70 \\
\hline 100,000 & 8.14 & 9.30 & 9.81 & 7.61 & 8.05 \\
\hline 125,000 & 8.19 & 11.69 & 11.71 & 10.34 & 8.17 \\
\hline 166,666 & 6.99 & 12.66 & 14.04 & 10.59 & 10.54 \\
\hline 200,000 & 10.52 & 10.52 & 9.74 & 11.66 & 12.21 \\
\hline Significance & $* * * *$ & $* * * *$ & $* * * *$ & $* * * *$ & $* * * *$ \\
\hline $\operatorname{LSD}(0.05)$ & 0.17 & 0.17 & 0.17 & 0.17 & 0.17 \\
\hline \multicolumn{6}{|l|}{ Summer } \\
\hline 62,500 & 9.77 & 16.05 & 14.02 & 13.07 & 11.14 \\
\hline 83,333 & 8.04 & 8.65 & 12.03 & 11.85 & 10.24 \\
\hline 100,000 & 8.03 & 9.39 & 10.53 & 9.52 & 7.34 \\
\hline 125,000 & 8.49 & 11.91 & 11.52 & 9.86 & 8.76 \\
\hline 166,666 & 10.44 & 13.18 & 12.26 & 11.81 & 12.32 \\
\hline 200,000 & 9.89 & 13.62 & 12.73 & 11.98 & 13.23 \\
\hline Significance & $* * * *$ & $* * * *$ & $* * * *$ & $* * * *$ & $* * * *$ \\
\hline $\operatorname{LSD}(0.05)$ & 0.13 & 0.13 & 0.13 & 0.13 & 0.13 \\
\hline
\end{tabular}

**** Significance at $\mathrm{P}=0.0001$, respectively. Means separated using the Least Significant Difference (LSD) at $\mathrm{P}=0.05$

There were significant $(\mathrm{P}<0.05)$ decreases in the oleic, palmatic and stearic acid content of safflower oil with increase in plant density from 62,500 to 100,000 plants $\mathrm{ha}^{-1}$, irrespective of genotype or growing season (Tables 2-4). However, for plant density in the range of 125,000-200,000 plants ha ${ }^{-1}$, oleic, palmatic and stearic acid contents generally increased without a consistent trend in all genotypes. Oleic acid content ranged between 11.1-23.2 and 13.3-23.4\% in winter and summer, respectively; depending on genotype and plant density (Table 2). The highest oleic fatty acid content was in genotype 'Kiama Composite' planted at 166,666 and 62,500 plants ha $^{-1}$, in winter $(23.2 \%)$ and summer $(23.4 \%)$, respectively (Table 2$)$. The lowest oleic fatty acid content was produced in winter
$(11.1 \%)$ and summer (13.3\%), in genotype 'Sina' at 166,666 and 125,000 plants ha $^{-1}$, respectively (Table 2).

Palmitic acid content of safflower seed oil ranged between 7.0-14.0 and 7.3-16.1\% in both winter and summer, respectively (Table 3). In winter and summer, the lowest palmitic acid content of safflower for all genotypes occurred at a plant density of 100,000 plants ha $^{-1}$, with the exception of 'Sina' and 'Gila', respectively (Table 3 ).

Stearic acid content of safflower seed oil ranged between 2.3-6.3 and 2.8-6.2\% in winter and summer, respectively, depending on genotype and plant density (Table 4). In winter and summer the highest stearic acid content was in the genotype 'Kiama Composite' planted at 166,666 and 62,500 plants ha ${ }^{-1}$ (Table 4). 
TABLE 4. Effect of genotype and plant density on stearic acid content of safflower oil under different seasons

\begin{tabular}{|c|c|c|c|c|c|}
\hline Plant density (plants ha' ${ }^{-1}$ ) & Sina & Gila & Kiama & PI-527710 & PI-537636 \\
\hline \multicolumn{6}{|l|}{ Winter } \\
\hline 62,500 & 3.61 & 5.63 & 5.67 & 5.33 & 4.09 \\
\hline 83,333 & 2.93 & 3.95 & 4.55 & 3.53 & 3.47 \\
\hline 100,000 & 2.73 & 3.21 & 3.44 & 3.09 & 2.84 \\
\hline 125,000 & 2.32 & 4.40 & 4.30 & 3.78 & 3.45 \\
\hline 166,666 & 3.37 & 5.33 & 6.33 & 3.35 & 3.88 \\
\hline 200,000 & 3.75 & 4.16 & 3.50 & 4.69 & 4.68 \\
\hline Significance & $* * * *$ & $* * * *$ & $* * * *$ & $* * * *$ & $* * * *$ \\
\hline $\operatorname{LSD}(0.05)$ & 0.070 & 0.070 & 0.070 & 0.070 & 0.070 \\
\hline \multicolumn{6}{|l|}{ Summer } \\
\hline 62,500 & 3.44 & 5.07 & 6.16 & 5.69 & 3.94 \\
\hline 83,333 & 2.99 & 3.86 & 4.86 & 4.27 & 3.85 \\
\hline 100,000 & 2.81 & 3.17 & 3.54 & 3.07 & 3.10 \\
\hline 125,000 & 3.11 & 4.47 & 4.50 & 3.48 & 3.05 \\
\hline 166,666 & 4.14 & 5.61 & 4.82 & 4.64 & 4.80 \\
\hline 200,000 & 3.49 & 5.30 & 5.26 & 4.52 & 5.80 \\
\hline Significance & $* * * *$ & $* * * *$ & $* * * *$ & $* * * *$ & $* * * *$ \\
\hline $\operatorname{LSD}(0.05)$ & 0.057 & 0.057 & 0.057 & 0.057 & 0.057 \\
\hline
\end{tabular}

**** Significance at $\mathrm{P}=0.0001$, respectively. Means separated using the Least Significant Difference (LSD) at $\mathrm{P}=0.05$

While genotype 'Sina' at 100,000 plants ha-1 had the lowest stearic acid content (Table 4). Similar to palmatic acid, genotype 'Sina' significantly $(\mathrm{P}<0.05)$ had the lowest stearic acid content than other genotypes in both winter and summer grown safflower in all plant densities (Table 4).

In both winter and summer grown safflower, arachidic, iso-oleic and iso-stearic acid were detected in the range between 0 $1.93,0-1.47$ and $0-1.6 \%$ as minor fatty acids depending on genotype, plant density and growing season, respectively (Figs.5-10). In winter or summer, arachidic fatty acid content in safflower seed oil was significantly $(\mathrm{P}<$ 0.05 ) higher in genotypes 'Sina' and 'PI537636 ' planted at 166,666 and 200,000 plants $\mathrm{ha}^{-1}$ than in the other genotypes planted in various plant densities (Figs. 5 and 6). Arachidic acid content was significantly $(\mathrm{P}<$ $0.05)$ lower or undetected in plant densities between 83,333-125,000 plants ha ${ }^{-1}$ in most genotypes irrespective of growing season (Figs. 5 and 6).

Iso-oleic acid content was also significantly $(\mathrm{P}<0.05)$ lower or undetected in plant densities between 83,333-125,000 plants ha ${ }^{-1}$ in most genotypes, in all seasons (Figs. 7 and 8). Iso-stearic acid content was significantly $(\mathrm{P}<0.05)$ higher in the genotype 'Kiama Composite' and 'PI-527710' planted at 166,666 or 62,500 plants ha ${ }^{-1}$ during winter or summer, respectively (Figs. 9 and 10).

There was a significant $(\mathrm{P}<0.05)$ interaction between genotype and plant density 
TABLE 5. Effect of genotype and plant density on unsaturated: saturated and oleic: linoleic fatty acid ratio under different seasons

\begin{tabular}{|c|c|c|c|c|c|c|c|c|c|c|}
\hline \multirow[t]{2}{*}{ Plant density (plants ha ${ }^{-1}$ ) } & \multicolumn{2}{|c|}{ Sina } & \multicolumn{2}{|c|}{ Gila } & \multicolumn{2}{|c|}{ Kiama } & \multicolumn{2}{|c|}{ PI-527710 } & \multicolumn{2}{|c|}{ PI-537636 } \\
\hline & Usa:sa & ole:lin & Usa:sa & ole:lin & Usa:sa & ole:lin & Usa:sa & ole:lin & Usa:sa & ole:lin \\
\hline \multicolumn{11}{|l|}{ Winter } \\
\hline 62,500 & 6.41 & 0.22 & 3.97 & 0.37 & 4.13 & $0.39 \mathrm{~b}$ & 4.44 & 0.36 & 5.14 & 0.32 \\
\hline 83,333 & 7.79 & 0.21 & 5.81 & 0.29 & 5.08 & $0.34 \mathrm{f}$ & 5.83 & 0.27 & 6.59 & 0.27 \\
\hline 100,000 & 8.56 & 0.17 & 7.03 & 0.15 & 6.55 & $0.24 \mathrm{~m}$ & 7.79 & 0.20 & 8.19 & 0.15 \\
\hline 125,000 & 8.00 & 0.17 & 5.22 & 0.32 & 5.25 & $0.34 \mathrm{f}$ & 6.13 & 0.28 & 7.60 & 0.22 \\
\hline 166,666 & 6.99 & 0.24 & 5.49 & 0.35 & 6.56 & $0.43 \mathrm{a}$ & 6.17 & 0.26 & 5.93 & 0.31 \\
\hline 200,000 & 6.01 & 0.26 & 4.35 & 0.29 & 3.71 & 0.210 & 5.11 & 0.32 & 4.68 & 0.37 \\
\hline Significance & $* * * *$ & $* * * *$ & $* * * *$ & $* * * *$ & $* * * *$ & $* * * *$ & $* * * *$ & $* * * *$ & $* * * *$ & $* * * *$ \\
\hline $\operatorname{LSD}(0.05)$ & 0.09 & 0.006 & 0.09 & 0.006 & 0.09 & 0.006 & 0.09 & 0.006 & 0.09 & 0.006 \\
\hline \multicolumn{11}{|l|}{ Summer } \\
\hline 62,500 & 6.59 & 0.26 & 3.58 & 0.34 & 3.70 & $0.43 \mathrm{a}$ & 4.13 & 0.36 & 5.32 & 0.33 \\
\hline 83,333 & 8.02 & 0.19 & 6.54 & 0.23 & 4.69 & $0.35 \mathrm{e}$ & 5.20 & 0.31 & 6.10 & 0.27 \\
\hline 100,000 & 8.22 & 0.18 & 7.46 & 0.25 & 6.11 & $0.26 \mathrm{k}$ & 6.94 & 0.23 & 8.57 & 0.19 \\
\hline 125,000 & 7.62 & 0.18 & 5.10 & 0.34 & 5.24 & $0.32 \mathrm{~h}$ & 6.04 & 0.27 & 7.47 & 0.23 \\
\hline 166,666 & 5.53 & 0.30 & 4.12 & 0.37 & 4.65 & $0.35 \mathrm{e}$ & 5.08 & 0.34 & 4.63 & 0.35 \\
\hline 200,000 & 6.47 & 0.27 & $4.09 \mathrm{u}$ & 0.37 & 4.37 & $0.36 \mathrm{~d}$ & 5.06 & 0.32 & 4.03 & 0.39 \\
\hline Significance & $* * * *$ & $* * * *$ & $* * * *$ & $* * * *$ & $* * * *$ & $* * * *$ & $* * * *$ & $* * * *$ & $* * * *$ & $* * * *$ \\
\hline $\operatorname{LSD}(0.05)$ & 0.04 & 0.003 & 0.04 & 0.003 & 0.04 & 0.003 & 0.04 & 0.003 & 0.04 & 0.003 \\
\hline
\end{tabular}

**** Significance at $\mathrm{P}=0.0001$, respectively. Means separated using the Least Significant Difference (LSD) at $\mathrm{P}=0.05$. Usa:sa Unsaturated: Saturated fatty acids; ole:lin Oleic acid: linoleic fatty acid content 


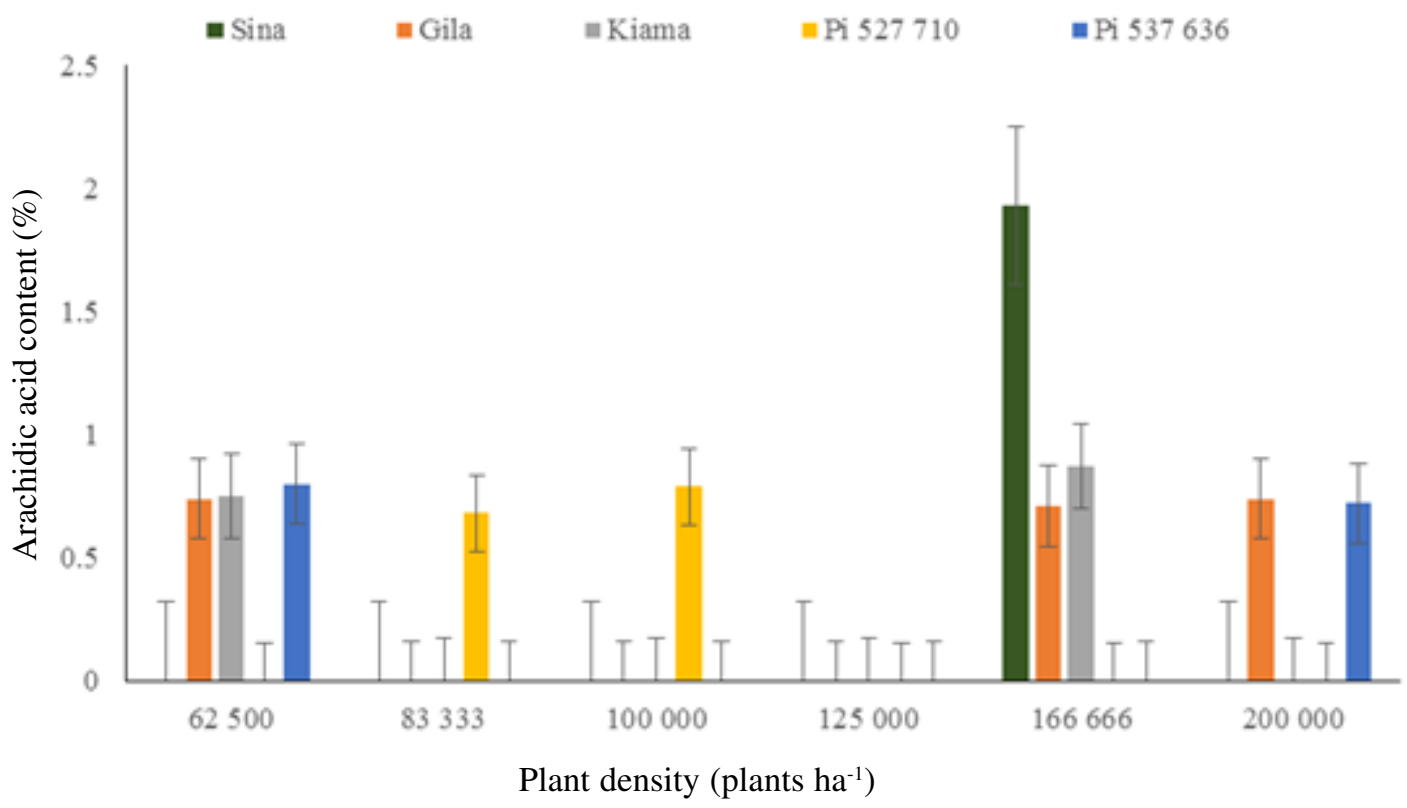

Figure 5. Effect of genotype and plant density on arachidic acid content of safflower oil produced from winter grown plants; bars are standard error.

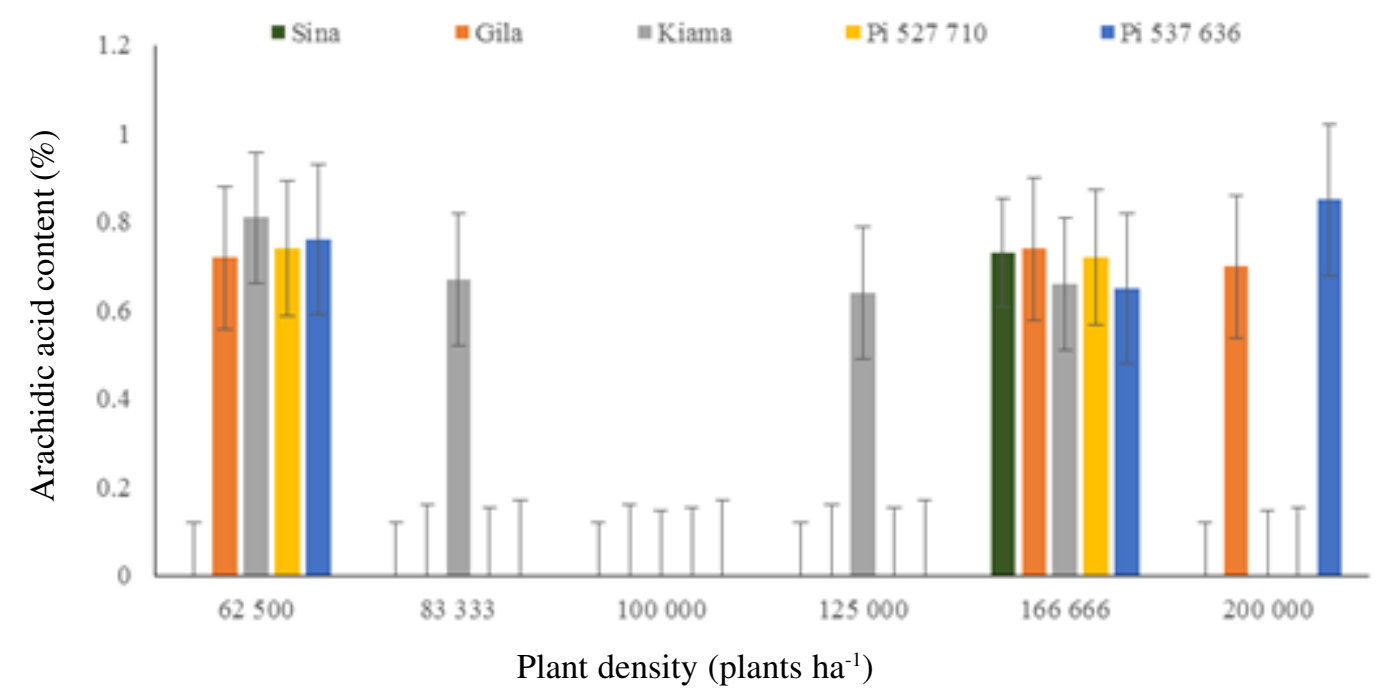

Figure 6. Effect of genotype and plant density on arachidic acid content of safflower oil produced from summer grown plants; bars are standard error. 


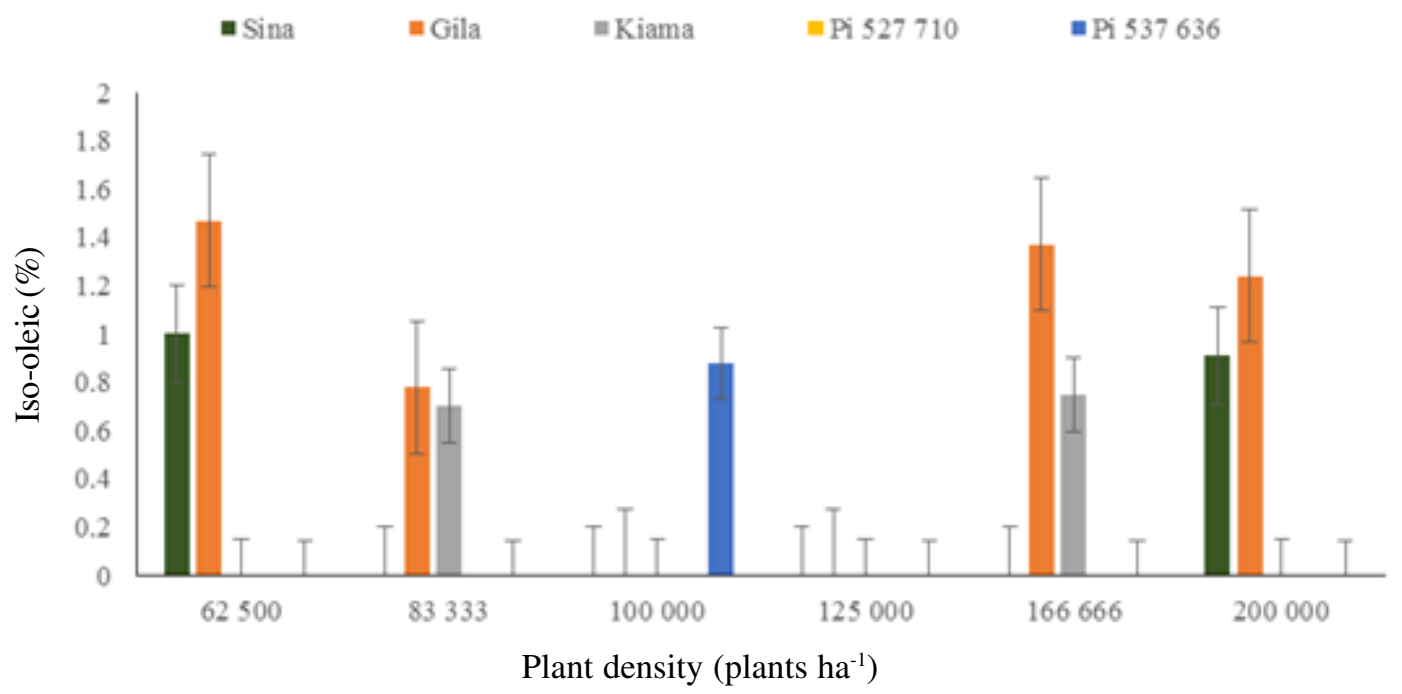

Figure 7. Effect of genotype and plant density on iso-oleic acid content of safflower oil produced from winter grown plants; bars are standard error.

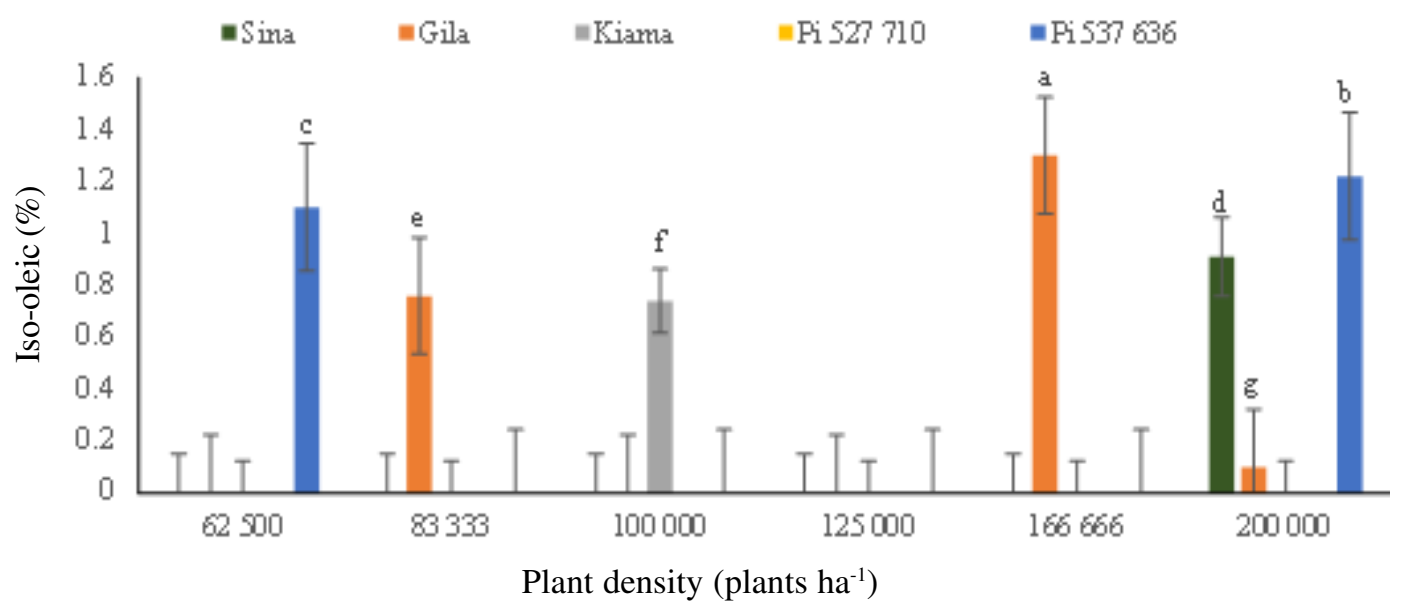

Figure 8. Effect of genotype and plant density on iso-oleic acid content of safflower oil produced from summer grown plants; bars are standard error. 


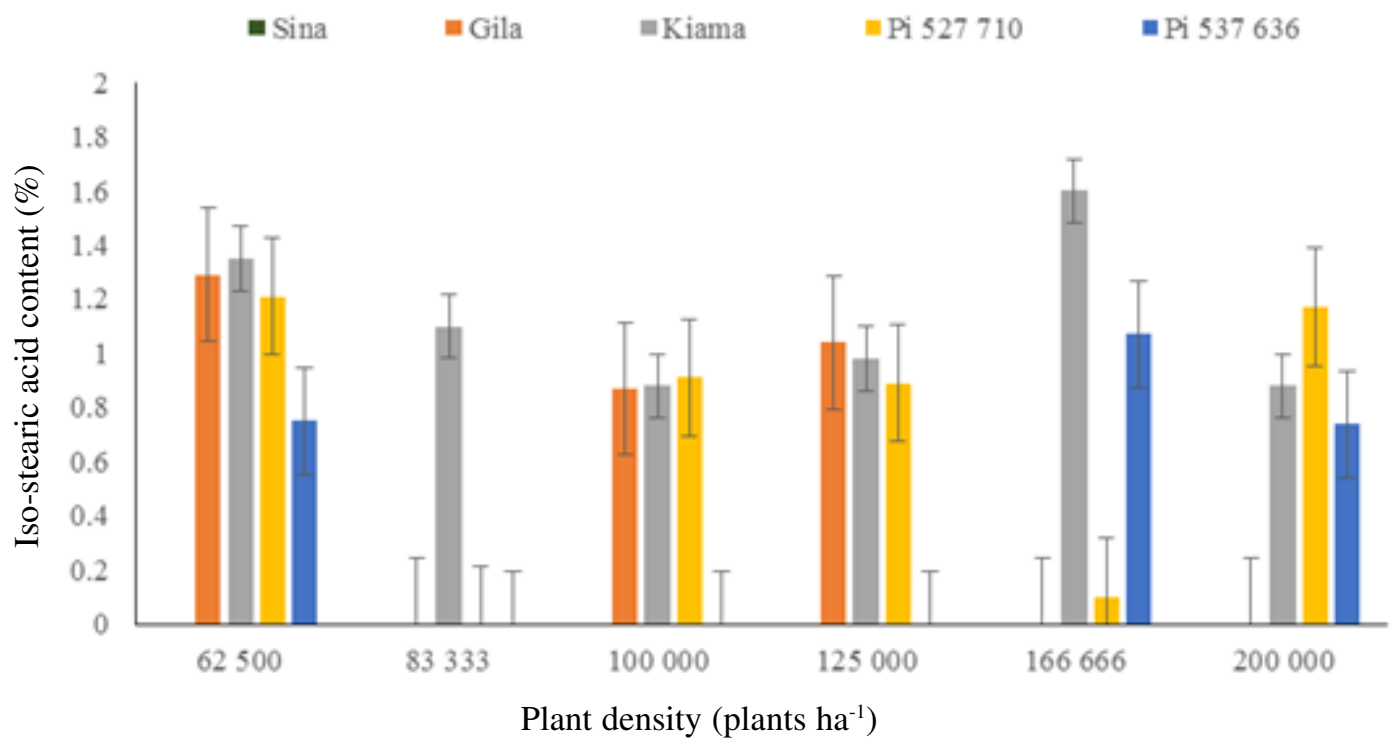

Figure 9. Effect of genotype and plant density on iso-stearic acid content of safflower oil produced from winter grown plants; bars are standard error.

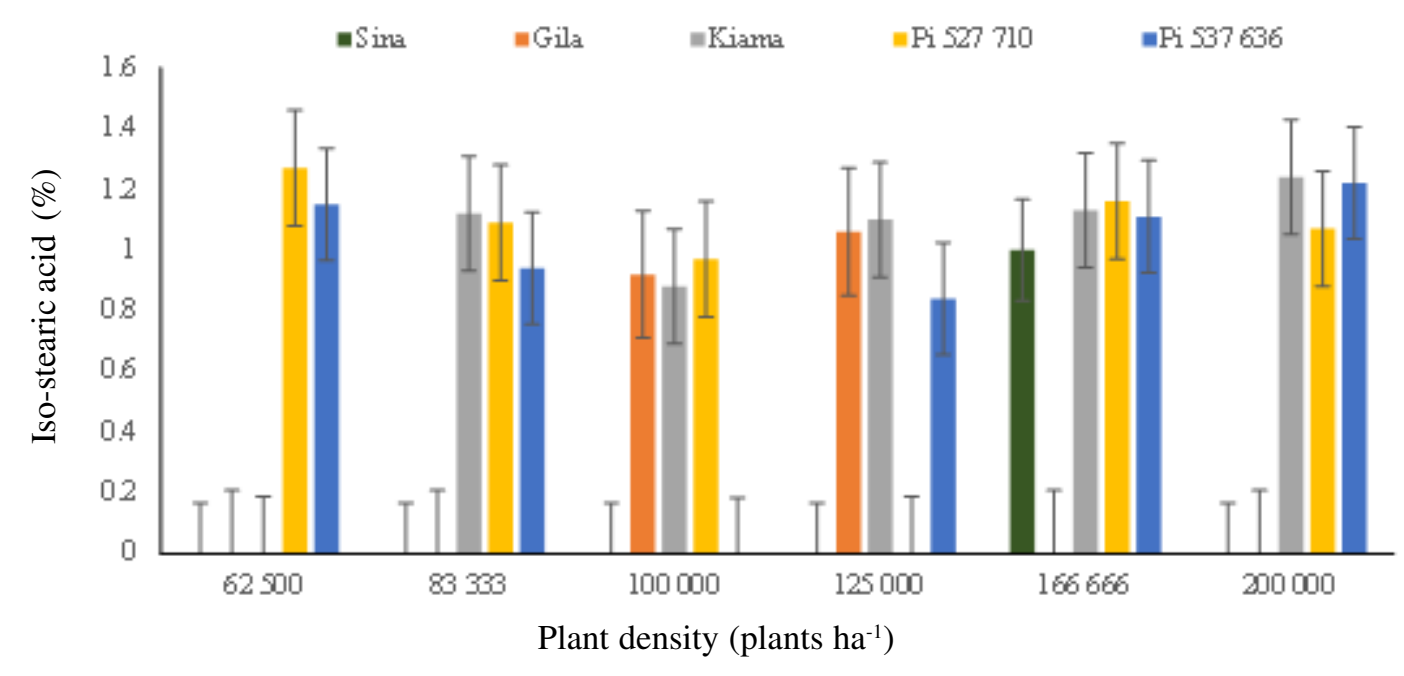

Figure 10. Effect of genotype and plant density on iso-stearic acid content of safflower oil produced from summer grown plants; bars are standard error.

on the unsaturated/saturated fatty acid ratio of safflower oil grown both in winter and summer (Table 5). The unsaturated/saturated fatty acid ratio of safflower oil significantly $(\mathrm{P}<0.05)$ increased with an increase in plant density from 62,500 to 100,000 plants $\mathrm{ha}^{-1}$, and thereafter, the unsaturated/saturated fatty acid ratio decreased with increase in plant density (Table 5). In winter and summer grown safflower, the unsaturated/saturated fatty acid ratio ranged from 3.71-8.57 and 3.58-8.57 with the highest experienced from plant density 100,000 plants ha $^{-1}$ by genotypes 'Sina' and 'PI-537636', respectively (Table 5). On the 
contrary, the oleic/linoleic acid ratio of safflower oil decreased with increase in plant density from 62,500 to 100,000 plants $\mathrm{ha}^{-1}$, and thereafter, the ratio increased in all genotypes for both seasons (Table 5). In winter and summer grown safflower, the oleic/linoleic acid ratio in the oil ranged between 0.15-0.43 and $0.18-0.43$, respectively (Table 5).

\section{DISCUSSION}

The significant interaction effects of genotype by plant density on fatty acid composition of safflower oil; linoleic, oleic, iso-oleic, palmitic, stearic, arachidic and iso-stearic (Tables 1-4; Figs. 5-10), implies that the safflower genotypes used in this study are suitable for human consumption and as livestock feeds. Liu et al. (2016) concluded that the suitability of a vegetable for a particular use depends on its fatty acid composition, which they noted to be significantly variable depending on the oil seed crop species. The major fatty acids of safflower identified in our study included linoleic (54-78\%), oleic (11-22\%), palmitic (7$16 \%)$ and stearic acid (2.3-6.2\%) depending on genotype, plant density and growing season. Various concentration ranges safflower fatty acids contents have been reported for geographical locations, genotypes, agronomic management, soils types and climatic conditions: for instance linoleic acid C18:2 (53.8-90.6\%), oleic acid C18:1 (7.5-35.3\%), palmitic acid C16:0 (4.9-11.2\%), and stearic acid C18:0 (1.7-2.8\%) (Fernández-Martinez et al., 1993; Cosge et al., 2007; Guan et al., 2008; Mailer et al., 2008; Vosoughkia et al., 2011; Aghamohammadreza et al., 2013; Khalid et al., 2017). Our study results on major fatty acid composition of safflower as influenced by the interaction of genotype, plant density and growing season are in agreement with what is reported widely in literature (Murthy and Anjani, 2008; Aghamohammadreza et al., 2013; Liu et al., 2016; Golkar et al., 2017), thus suggesting a genetic variation in fatty acid profiles, which is important for the genetic improvement of safflower oil breeding for quality improvement.

The rise in linoleic fatty acid and concurrent decrease in oleic, stearic, palmitic fatty acids, and oleic/linoleic acid ratio, and the lack or minimal arachidic, iso-oleic, iso-stearic composition observed in the present study, with increasing plant density from 62,500 to 100,000 plants ha ${ }^{-1}$ (Table 5), demonstrates an inverse relationship between various types of fatty acids. Fernández-Martinez et al. (1993) and Johnson et al. (1999) reported significant negative correlations $(\mathrm{r}=-0.83$ and - 0.98, respectively) for linoleic fatty acid and oleic fatty acid contents. They attributed the inverse relationship between linoleic and oleic fatty acids to oleic, stearic and palmitic fatty acids desaturated to form linoleic fatty acid. Similar results have been reported by several authors (Jianguo et al., 1993; Johnson et al., 1999; Gecgel et al., 2007; Rudolphi et al., 2012; Liu et al., 2016) with similar attributions. Furthermore, the amount of oleic fatty acid compared to linoleic fatty acid has been reported to be related to the differential expression of fatty acid desaturase enzymes that control the conversion of oleic fatty acid to linoleic fatty acid (Aguirrezabal et al., 2015; Khan et al. 2018).

The unsaturated fatty acids (linoleic and oleic) and the saturated fatty acids (palmitic and stearic) in safflower oil accounted for 65$100 \%$ and $9.3-22 \%$, respectively (Table 5), depending on genotype, plant density and growing season; which was within the recommended range (Fernández-Martinez et al., 1993; Cosge et al., 2007; Guan et al., 2008; Mailer et al., 2008; Vosoughkia et al., 2011; Aghamohammadreza et al., 2013; Khalid et al., 2017). The results attest to the high quality of Botswan's safflower oil, perhaps due to high proportions of polyunsaturated (linoleic) and monounsaturated (oleic) fatty acids compared to saturated fatty acids (stearic and palmitic) and minor fatty acids. The high proportions of polyunsaturated fatty acids and tocopherols in these safflower genotypes' oil, 
make it highly suitable for used for medicinal and dietetic purposes (Velasco et al., 2005; Cosge et al., 2007; Han et al., 2009; Liu et al., 2016).

The significant variation in fatty acid composition among the safflower genotypes planted in various plant densities and growing season observed (Table 1-4; Figs 5-10) is largely accounted for by differences among the genotypes. Genetic control of safflower fatty acid composition has been reported fairly extensively (Golkar et al., 2012; Golkar, 2014; Bellaloui et al., 2015; Golkar et al., 2017). Zhang et al. (2015) reported that the fatty acid composition of most oil seed crops is determined by their taxonomic affiliation compared to climate. Knowles (1989) earlier reported that the genotypes $O L O L$ and olol genes were more stable with regard to temperature changes, in contrast to the gene $o l_{1}$. At the highest temperature, in the genotype $\mathrm{ol}_{l} \mathrm{ol}_{l}$ and $\mathrm{OLol}$, the linoleic fatty acid content is slightly decreased; while oleic fatty acid increased by the corresponding amount.

\section{CONCLUSION}

The results of the present study show that safflower can be grown both in winter and summer in Southern Africa with minimum alterations on the fatty acids profiles. There were significant interactions of safflower genotypes with plant density as influenced by growing season in oil content and fatty acid composition, indicating genetic, plant density, and genetic $\mathrm{x}$ environmental effects. All the five genotypes evaluated in the present study qualify for commercial oil production provided they are planted at 100,000 plants ha ${ }^{-1}(40 \mathrm{~cm}$ x $25 \mathrm{~cm})$. Genotype 'Sina' was the best performing producing high oil content of excellent quality and the oil content was stable in all growing seasons. The major fatty acids in five genotypes evaluated were linoleic acid (polyunsaturated) and oleic acid (monounsaturated).

\section{ACKNOWLEDGEMENT}

The authors are grateful to the MasterCard Foundation and Regional Universities Forum for Capacity Building in Agriculture (RUFORUM) for funding research and publication cost through the Transforming African Agricultural Universities to meaningfully contribute to Africa's growth and development (TAGDev) Program.

\section{REFERENCES}

Aghamohammadreza, M., Mirhadi, M.J., Delkhosh, B. and Omidi, A. 2013. Evaluation of native and exotic safflower (Carthamus tinctorius L.) genotypes for some important agronomic traits and fatty acid composition. Annals of Biology Research 4(6):200-204.

Aguirrezabal, L., Marte, P., Pererya-Irujo, G., Echarte, M. M. and Izquierdo, N. 2015. Improving grain quality: Eco physiological and modelling tools to develop management and breeding strategies. Genetic Improvement and Agronomy 17:423-464.

Amoughein, R., Tobeh, A. and Jamaati-ESomarin, S. 2012. Study on the effect of different plant density on some morphological traits and yield of safflower under irrigated and rainfed planting conditions. International Journal of Agronomy and Plant Production 3(8):284290.

AOAC. 1996. Association of Official Analytical Chemists Official Methods of Analysis. $17^{\text {th }}$ Edition, Arlington, Virginia, USA.

AOACS. 2004. Association of Official Analytical Chemists Society. Official methods and recommended practices of the AOCS. The American Oil Chemists Society, Methods, additions and revisions, pp. 1-2. Bannayan, M., Nadjafi, F., Aziz, M., Tabrizi, L. and Rastgoo, M. 2008. Yield and seed quality of Plantagoovata and Nigellasativa under different irrigation treatments. Industrial Crops and Products 27:11-16. 
Bellaloui, N., Bruns, H. A., Abbas, H. K., Mengistu, A., Fisher, D. K. and Reddy, K. N. 2015. Agricultural practices altered soybean seed protein, oil, fatty acids, sugars and minerals in the Midsouth USA. Frontiers in Plant Science 31(6):1-13.

Burgess, J. 2006. Country Pasture/ Forage Resource Profiles: Botswana. Food Agricultural Organisation. 45pp.

Cosge, B., Gurbuz, B. and Kiralan, M. 2007. Oil content and fatty acid composition of some safflower (Carthamus tinctorius L.) varieties sown in spring and winter. International Journal of Natural and Engineering Sciences 1:11-15.

Cucci, G., Rotunno, T., Lacolla, G. and Di Caterina, R. 2012. The effect of plant density with different row spacing on quality of fatty acid composition and grain yield of sunflower. African Journal Biotechnology 11(102):16688-16696.

De-Wilt, P. V. and Nightengaele, F. O. 1996. Explanatory notes on soil map of Republic of Botswana. Soil mapping and advisory services. Botswana. 48p.

Dwivedi, S., Upadhyaya, L. and Hedge, D. M. 2005. Development of core collection using geographic information and morphological descriptors in safflower (Carthumus tinctorius L.) germplasm. Genetics Research Crop Evolution 52:821-830.

Emongor, V.E. 2010. Safflower (Carthamus tinctorius L.) the underutilized and neglected crop: A review. Asian Journal of Plant Science 9(6):299-306.

Emongor, V.E., Oagile, O. and Kedikanetswe, B. 2013. Effects of plant population on growth, development and oil yield of safflower. Journal of Agricultural Science and Technology 3:321-333.

Emongor, V.E., Oagile, O. and Kedikanetswe, B. 2015. Effects of plant population and season on growth and development of safflower (Carthamus tinctorius L.) as an ornamental plant. Acta Horticulturae 1077: $35-45$.
Emongor, V.E. and Oagile, O. 2017. Safflower Production. Impression House Publication, Botswana, ISBN 978-99968-0-607-0. 62p. Emongor, V.E., Orabile, P., Phuduhudu, D. and Oagile, O. 2017. Effects of genotype on vegetative growth, yield components and yield, oil content and oil yield of safflower. Agricultural Science Research Journal 7(12):381-392.

FAO. 2013. Crop water information: Safflower. Water Development and Management Unit, Food and Agriculture Organization Publication. 8p.

Fernández- Martínez, J., Rio, D. and Haro de, A. 1993. Survey of safflower (Carthamus tinctorius L.) germplasm for variants in fatty acid composition and other seed characters. Euphytica 69:115-122.

Gecgel, U., Demirci, M., Esendal, E. and Tasan, M. 2007. Fatty acid composition of the oil from developing seeds of different varieties of safflower (Carthamus tinctorious L.). Journal of American Oil Chemist Society 84:47-54.

Golkar, P. 2014. Breeding improvements in safflower (Carthamus tinctoriuos L.). A review. Australian Journal Crop Science 8(7):1079-1085.

Golkar, P., Arzani, A. and Rezaei, A.M. 2012. Genetic analysis of agronomic traits in safflower (Carthamus tinctoriuos L.). Notulae Botanica Horti Agrobotanica Cluj-Napoca 40(1):276-281.

Golkar, P., Shahbazi, E. and Nouraein, M. 2017. Combining ability $\mathrm{x}$ environment interaction and genetic analysis for agronomic traits in safflower (Carthumus tinctorious L.): biplot as a tool for diallel data. Acta Agriculture Slovenica. pp. 236235.

Guan, L.L., Wu, W. and Zheng, Y.L. 2008. Seed and fatty acids of different safflower genotypes and their correlations with agronomic traits and photosynthetic parameters. The Phillippine Agricultural Science 91(4):383-388. 
Han, X., Cheng, L., Zhang, R. and Bi, J. 2009. Extraction of safflower seed oil by supercritical $\mathrm{CO}_{2}$. Journal of Food Engineering 92:370-376.

Ibrahim, H. M. 2012. Response of some sunflower hybrids to different levels of plant density. APCBEE Proceedings 4:175182.

Jianguo, Y., Zhong, J. Y. and Xu, Y. 1993. The research on the germplasm resources of safflower with different contents of fatty acids. $3^{\text {rd }}$ International Safflower Conference, Beijing 14-18.

Johnson, R.C., Bergmann, J.W. and Flynn, C.R. 1999. Oil and meal characteristics of core and non-core safflower accessions from USDA collection. Genetic Research Crop Evolution 46:611-618.

Khalid, N., Khan, S.R., Hussain, M.I., Farooq, M., Ahmad, A. and Ahmed, I. 2017. A comprehensive characterization of safflower oil for its potential applications as a bioactive food ingredient: A Review. Trends in Food Science and Technology 66: 176-186.

Khan, S., Anwar, S., Noman, A., Shahid, M., Din, M., Ali, A. and Zhou, G. 2018. Alteration in yield and oil quality traits of winter rapeseed by lodging at different planting density and nitrogen rates. Scientific Reports 8:1-12.

Liu, L., Guan, L. and Yang, Y. 2016. A review of fatty acid and genetic characterization of safflower (Carthamus tinctorius L.) seed oil. World Journal of Traditional Chinese Medicine 2(2):48-52.

Mailer, R., Potter, T., Redden, R. and Ayton, J. 2008. Quality evaluation of safflower (Carthamus tinctorius L) cultivars. $7^{\text {th }}$ International Safflower Conference, Wagga Wagga, New South Wales, Australia. pp. 1-8.

Mollasadeghi, V., Valizadeh, M., Shahryari, R. and Imani, A.A. 2011. Evaluation of end drought tolerance of 12 wheat genotypes by stress indices. Middle-East Journal of Scientific Research 7(2):241-247.
Murthy, I.Y.L.N. and Anjani, K. 2008. Fatty acid composition in Carthamus species. Proceedings of the $7^{\text {th }}$ International Safflower Conference, $3^{\text {rd }}-6^{\text {th }}$ November, Wagga Wagga, NSW, Australia. pp. 1-3.

Oad, M.A., Samo, S.M., Qayyum, S.M. and Oad, N.L. 2002. Inter and intra row spacing effect on the growth, seed yield and oil content of safflower (Carthumus tinctorious L.). Asian Journal of Plant Science 1(1):18-19.

Oarabile, P. 2017. Effects of safflower (Carthamus tinctorius L.) genotypes on growth, development, yield and yield components, and oil content and yield. MSc Thesis Botswana University of Agriculture and Natural Resources, Faculty of Agriculture. 81pp.

Phuduhudu, D. 2017. Evaluation of the nutritional potential of safflower (Carthamus tinctorius L.) leaves, seed and cake after oil extraction to be used as animal feed. MSc Thesis, Botswana University of Agriculture and Natural Resources, Faculty of Agriculture, University of Botswana

Rudolphi, S., Becker, H.C., Schierholt, S. and von Witzke-Ehbrecht, S. 2012. Improved estimation of oil, linoleic and oleic acid and seed hull fractions in safflower by NIRS. Journal American Oil Chemist Society 89: 363-369.

Sampaio, M.C., Santos, R.F., Bassegio, D., de Vasconselos, E.S., de Silveira, L., Lenz, N.B.G., Lewandoski, C.F. and Tokuro, L.K. 2017. Effect of plant density on oil yield of safflower. African Journal of Agricultural Research 12(25):2147-2152.

Sarkees, N.A. and Mohammed, B.I. 2016. Effect of plant densities on seed yield and quality of two cultivars of safflower (Carthamus tinctorius L.). Polytechnic 6(1):287-292.

Smith, J.R. 1996. Safflower. AOCS Press, Champaign, IL. U.S.A. pp. 624-627.

Velasco, L. and Fernandez-Martinez, J.M. 2001. Breeding for oil quality in safflower. In: Bergman, J.W. and Mundel, H.H. 
(Eds.). Proceedings of the $5^{\text {th }}$ International Safflower Conference, Williston, North Dakota and Sidney, Montana, United States of America. pp. 133-137.

Velasco, L., Perez-Vich, B. and FernandezMartinez, J.M. 2005. Identification and genetic characterization of a safflower mutant with modified tocopherol profile. Plant Breeding 124:459-473.

Vosoughkia, M., Ghareaghag, H.L., Ghavami, M., Gharachorloo, M. and Delkhosh, B. 2011. Evaluation of oil content and fatty acid composition in seeds of different genotypes of safflower (Carthumus tinctorius L.). International Journal of Agricultural Science and Research 2(1): 5966.

Weiss, E.A. 2000. Oilseed Crops. $2^{\text {nd }}$ Edition, England, Blackwell Science Oxford. pp. 93-129.

Zhang, J, Zhang, S., Zhang, Y. and Kitajima, K. 2015. Effect of phylogeny and climate on seed oil fatty acid composition across 747 plant species in China. Industrial Crops and Products 63:1-8. 